\title{
Glucose oxidase inhibition in poly(neutral red) mediated enzyme biosensors for heavy metal determination
}

\author{
Mariana Emilia Ghica Christopher M. A. Brett
}

Received: 27 November 2007 / Accepted: 15 February 2008 / Published online: 11 March 2008

(C) Springer-Verlag 2008

\begin{abstract}
A biosensor for the determination of heavy metal cations based on glucose oxidase enzymatic inhibition has been developed. The biosensor was assembled on carbon film electrode supports with glucose oxidase immobilised by cross-linking with glutaraldehyde on top of a film of poly(neutral red) as redox mediator, prepared by electropolymerisation. The biosensor was used to determine the metallic cations, cadmium, copper, lead and zinc in the presence of chosen amounts of glucose. The detection limits were found to be $1 \mu \mathrm{g} \mathrm{L}{ }^{-1}$ for cadmium, $6 \mu \mathrm{g} \mathrm{L}^{-1}$ for copper, $3 \mu \mathrm{g} \mathrm{L}^{-1}$ for lead and $9 \mu \mathrm{g} \mathrm{L}{ }^{-1}$ for zinc. Inhibition constants were determined by using the Dixon plot, and the type of inhibition induced by the metallic cations was evaluated from Cornish-Bowden plots plus Dixon plots, it being found that the inhibition is reversible and competitive for cadmium, mixed for copper and lead and uncompetitive for zinc. Copper-inhibited glucose oxidase to a greater extent followed by cadmium, lead and zinc. Regeneration of the glucose oxidase response was studied by using Ethylene diamine tetracetic acid metal-chelating agent and the nonionic surfactant Triton X-100. The suitability of the biosensor for determination in foodstuffs or beverages which contain trace concentrations of metals was investigated by performing recovery tests in commercial milk samples.
\end{abstract}

Keywords Enzymatic inhibition · Heavy metal cations . Carbon film electrode - Glucose oxidase .

Poly(neutral red) redox mediator

M. E. Ghica · C. M. A. Brett $(\bowtie)$

Departamento de Química, Faculdade de Ciências e Tecnologia, Universidade de Coimbra,

3004-535 Coimbra, Portugal

e-mail: brett@ci.uc.pt

\section{Introduction}

Heavy metal ions are ubiquitous in nature, industrial activity being one of the potential sources of contamination, thus, resulting in a serious environmental problem. Generally, these metals are very toxic for living organisms, being dangerous to human health when present in drinking water and food. Studies on the biological effects caused by heavy metals have been published $[1,2]$. Due to their high toxicity, there is an obvious need to determine trace levels of them rapidly in situ. Methods widely used for the determination of these metal ions are atomic absorption spectrometry [3], inductively coupled plasma mass spectrometry [4] or ion exchange chromatography [5]. These methods require very sophisticated equipment, qualified personnel, complicated pretreatment of the samples and long detection time and are not adequate for field measurements. Therefore, it is desirable to develop a simple and easy method for the detection of these ions. Electrochemical methods can satisfy these requirements: electrochemical devices can be made to be portable and with excellent sensitivity; therefore, they represent a good alternative for heavy metals field monitoring [6], especially by using anodic stripping voltammetry [7].

Enzymatic sensors are a promising alternative for the detection of these toxic substances in water, soil, air and food products. Enzyme inhibition assays have the potential to rapidly screen and identify heavy metals in environmental samples. Heavy metals are well known to inhibit the activity of enzymes, and application to the determination of hazardous toxic elements offers several advantages. Biosensors based on inhibition are usually far more sensitive to the determination of the inhibitor compared to the determination of the enzymatic substrate. The detection limit is normally much lower than the maximum admissible value in environmental and clinical samples and much lower than 
the value obtained by traditional methods $[8,9]$. Inhibition biosensors include lactate dehydrogenase [10], glucose oxidase (GOx)[11], pyruvate oxidase [12], L-glycerol phosphate oxidase [12] and urease [13], normally for the determination of mercury ions. Other studies report the inhibition of alcohol oxidase by silver, copper and lead [14] or of glucose oxidase by silver, mercury and lead ions [15].

The present study focuses on the simple and rapid determination of several metal cations, namely cadmium, copper, lead and zinc, through the inhibition of the enzyme glucose oxidase using an amperometric glucose biosensor with poly(neutral red) (PNR) as redox mediator. Neutral red (NR), an acid-base indicator with $\mathrm{p} K_{\mathrm{a}} \sim 6.8$ from the family of azines, can be electropolymerised via the formation of a cation radical by electro-oxidation [16], and poly(neutral red) has been applied as a redox mediator in various oxidase enzyme electrodes [17, 18]. Although glucose oxidase is a well-characterised and used enzyme in sensors, it has been little used in inhibition biosensors for heavy metals. To our knowledge, there are only three reports concerning the inhibition of glucose oxidase by heavy metals, and just one of these [19] uses an electrochemical method. The metal cations were determined at the microgram-per-litre level in the presence of chosen amounts of glucose, and the inhibition induced by these metals was investigated in terms of reversibility and competition. The possibility of applying the method to natural sample screening was evaluated by performing recovery tests in milk samples, and the stability under storage conditions was evaluated. Because many biosensors make use of immobilised enzyme on a probe for continuous use, the ability to reuse GOx in repeated measurements of metal concentrations was investigated by using ethylene diamine tetracetic acid (EDTA) and Triton additions as a means of quickly restoring the enzymatic activity of GOx.

\section{Experimental}

Materials and reagents

GOx (EC 1.1.3.4, from Aspergillus niger, $24 \mathrm{U} \mathrm{mg}^{-1}$ ) was from Fluka (www.sigmaaldrich.com), glutaraldehyde (GA; $25 \% v / v)$, bovine serum albumin (BSA) and $\alpha-\mathrm{D}(+)$-glucose were purchased from Sigma (www.sigmaaldrich.com). Neutral Red was from Aldrich (www.sigmaaldrich.com).

Other reagents used were: cadmium sulphate $\left(\mathrm{CdSO}_{4}\right)$, copper chloride $\left(\mathrm{CuCl}_{2}\right)$, lead nitrate $\left(\mathrm{Pb}\left(\mathrm{NO}_{3}\right)_{2}\right)$ and zinc sulphate $\left(\mathrm{ZnSO}_{4}\right)$ from Merck (www.merck.com). EDTA was from Fluka (www.sigmaaldrich.com) and Triton X-100 was from Sigma (www.sigmaaldrich.com).

For neutral red electropolymerisation, potassium phosphate buffer $\mathrm{pH} 6.0$ was prepared using $0.025 \mathrm{M} \mathrm{K}_{2} \mathrm{HPO}_{4} /$
$\mathrm{KH}_{2} \mathrm{PO}_{4}$ from Panreac (www.panreac.es) and 0.1 $\mathrm{M} \mathrm{KNO}_{3}$ from Riedel-de-Haën (www.riedeldehaen.de).

For all the other electrochemical experiments, the supporting electrolyte was $0.1 \mathrm{M}$ sodium phosphate buffer saline (NaPBS), pH 7.0, prepared from sodium dihydrogenphosphate and disodium hydrogenphosphate and $0.05 \mathrm{M} \mathrm{NaCl}$ from Riedel-de-Haën (www.riedeldehaen.de). Millipore Milli-Q nanopure water (resistivity $>18 \mathrm{M} \Omega \mathrm{cm}$; www. millipore.com) was used for preparation of all solutions. Experiments were performed at room temperature, $25 \pm 1{ }^{\circ} \mathrm{C}$.

\section{Electrode preparation}

Cylindrical carbon film electrodes of diameter $1.5 \mathrm{~mm}$ and length $4 \mathrm{~mm}$ were made from carbon film resistors (nominal resistance $2 \Omega$ ), following an electrode preparation protocol described elsewhere [20, 21]. The exposed electrode geometric area was $\sim 0.20 \mathrm{~cm}^{2}$. Before use, the electrodes were electrochemically pretreated by cycling the applied potential between 0.0 and $+1.0 \mathrm{~V} v s$. saturated calomel electrode (SCE) in $0.1 \mathrm{M} \mathrm{KNO}_{3}$ solution for not less than ten cycles, until stable cyclic voltammograms were obtained.

Poly(neutral red) films were obtained by electrochemical polymerisation as described previously [17]. NR was polymerised by cycling the applied potential between -1.0 and $+1.0 \mathrm{~V} v s$. SCE for 15 times at a scan rate of $50 \mathrm{mV} \mathrm{s}^{-1}$ in a solution containing $1 \mathrm{mM} \mathrm{NR}$ monomer, $0.025 \mathrm{M}$ potassium phosphate buffer pH 6.0 and $0.1 \mathrm{M} \mathrm{KNO}_{3}$.

GOx was immobilised by the cross-linking method. A mixture of enzyme with glutaraldehyde, as cross-linking agent, and BSA protein was used. The mixture contained $10 \mu \mathrm{L}$ enzyme solution ( $40 \mathrm{mg} \mathrm{mL}^{-1} \mathrm{BSA}$ and $10 \mathrm{mg} \mathrm{mL}^{-1}$ GOx in phosphate buffer) and $5 \mu \mathrm{L}$ GA (2.5\% in water). From this mixture, $10 \mu \mathrm{L}$ were placed on top of the poly (neutral red)-modified carbon film electrodes and allowed to dry at room temperature for at least $1 \mathrm{~h}$. When not in use, electrodes were kept in phosphate buffer solution $\mathrm{pH} 7.0$ at $4{ }^{\circ} \mathrm{C}$.

\section{Instruments}

A three-electrode electrochemical cell was used for electrochemical measurements. It contained the PNR/GOxmodified carbon film working electrode, a platinum foil as counter electrode and SCE as reference. Electrochemical measurements were performed using a Bioanalytical Systems (BAS, West Lafayette, IN, USA, www.bioanalytical. com) CV-50 W electrochemical analyzer, controlled by BAS CV 2.1 software.

The $\mathrm{pH}$ measurements were carried out with a CRISON 2001 micro pH-meter (www.crison.es). 
Procedure for enzyme inhibition studies

The PNR-GOx-modified electrode was dipped into a stirred phosphate buffer solution at $\mathrm{pH} \mathrm{7.0,} \mathrm{and} \mathrm{a} \mathrm{fixed}$ potential of $-0.35 \mathrm{~V}$ vs. SCE was applied. After stabilisation of the baseline current, a known amount of glucose was added, and the steady-state current was recorded. Finally, solutions of increasing metal concentrations were added successively to inhibit the glucose oxidase activity, and the current decrease, which is proportional to the final concentration of the inhibitor in solution, was recorded.

\section{Results and discussion}

Glucose biosensor with poly(neutral red) redox mediator

Poly(neutral red) films were prepared on the carbon film electrode substrate by potential cycling as described in the experimental section. Figure 1 shows successive cyclic voltammograms during film growth. At high positive potentials, around $+0.85 \mathrm{~V}$ vs. SCE, irreversible oxidation of the monomer occurs (peak $\mathrm{C}$ ), and at negative potentials, between -0.45 and $-0.65 \mathrm{~V}$, a redox pair (peaks $\mathrm{A} / \mathrm{A}^{\prime}$ ) appears corresponding to oxidation-reduction of the polymer, also overlapping with monomer oxidation-reduction. The increase in peak height is evidence of growing of the polymer film. Further details are given in [18].

Glucose oxidase enzyme was immobilised by glutaraldehyde cross-linking on top of the PNR film, as described in "Experimental", in order to make the glucose biosensor. The response of the PNR-GOx biosensor to glucose was an increase in anodic current, which was linear up to $1.8 \mathrm{mM}$, and the detection limit was found to be $22 \mu \mathrm{M}$ [17]. Several investigative studies have been carried out leading to the proposal of a mechanism for the PNR-GOx biosensor as a competition between flavin adenine dinucleotide (FAD) cofactor regeneration and hydrogen peroxide reduction. A study of the influence of oxygen on the mediator functioning has also been performed, showing that for glucose oxidase immobilised by the cross-linking method (as here), the response to glucose is almost unchanged [18].

Inhibition studies

To study the effect of the metal cations on the activity of the enzyme glucose oxidase, the response of the biosensor in their presence was evaluated following the procedure described in the "Experimental" section in phosphate buffer solution at $\mathrm{pH} 7.0$.

It is well known that the $\mathrm{pH}$ can affect enzyme activity, leading to the denaturation of the enzyme at extreme values. The $\mathrm{pH}$ also can influence the heavy metal action:

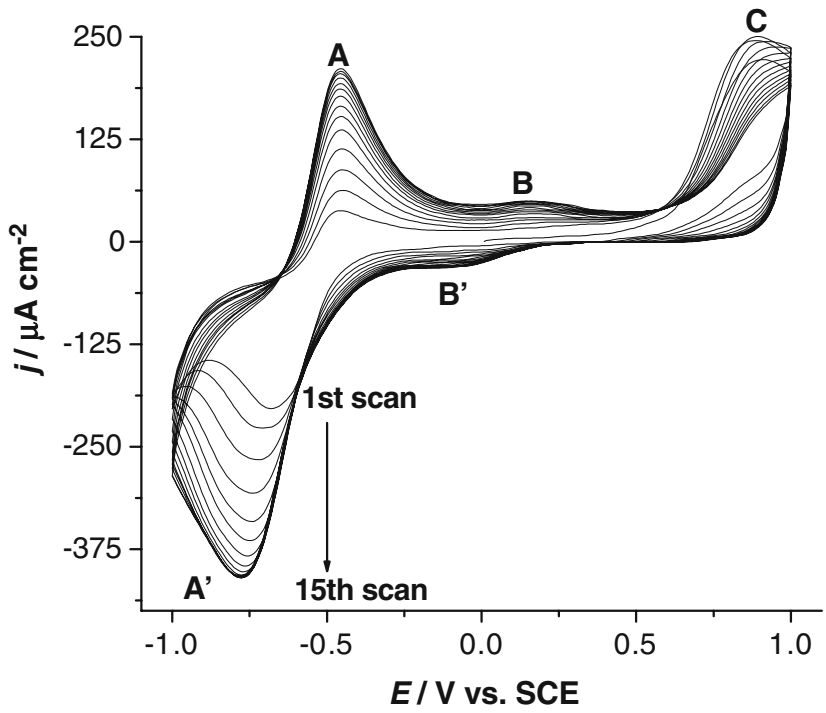

Fig. 1 Cyclic voltammetry of neutral red electropolymerisation on carbon film electrode. $1 \mathrm{mM} \mathrm{NR}$ in $0.025 \mathrm{M} \mathrm{KPB}+0.1 \mathrm{M} \mathrm{KNO}_{3} \mathrm{pH}$ 6.0. Scan rate $50 \mathrm{mV} \mathrm{s}^{-1}$

different $\mathrm{pH}$ values can be chosen in order to avoid interferences, in this way, achieving selective inhibition because different heavy metals should have different affinities for binding to the active site. For instance, Mohammadi et al. [22] investigated the effect of $\mathrm{pH}$ in order to improve the selectivity of invertase toward mercury and to avoid silver interference, and medium exchange was carried out. In the present work, all experiments were performed in phosphate buffer solution $\mathrm{pH}$ 7.0, chosen because it was previously observed [17] that it is a good compromise between having a good enzyme activity and good redox mediator functioning. It was decided to study the inhibition of metal cations under the same conditions in order to evaluate their influence on the response of the glucose biosensor when applied to determinations in natural samples.

The determination of cadmium and copper was performed in the presence of a fixed glucose concentration; the calibration curves for these two cations are presented in Fig. 2. Cadmium was measured from 4 to $81 \mu \mathrm{g} \mathrm{L}^{-1}$ being linear up to $16 \mu \mathrm{g} \mathrm{L}^{-1}$ and having a detection limit (three times the noise to signal ratio) of $1 \mu \mathrm{g} \mathrm{L}^{-1}$ (Fig. 2a). The determination of copper was carried out between $33 \mu \mathrm{g} \mathrm{L}^{-1}$ and $2.3 \mathrm{mg} \mathrm{L}^{-1}$ (Fig. 2b) with a linear range up to $0.58 \mathrm{mg} \mathrm{L}^{-1}$, and the detection limit was $6 \mu \mathrm{g} \mathrm{L}^{-1}$ (see Table 1). The detection limit for copper achieved by the present method is lower than that reported in previous studies [10, 14].

In order to evaluate the inhibition of the activity of glucose oxidase, the following expression was used:

$I(\%)=100\left(I_{1}-I_{2}\right) / I_{1}$

where $I$ represents the degree of inhibition, $I_{1}$ represents the response to glucose in the absence of inhibitor and $I_{2}$ represents the response to glucose in the presence of inhibitor. 

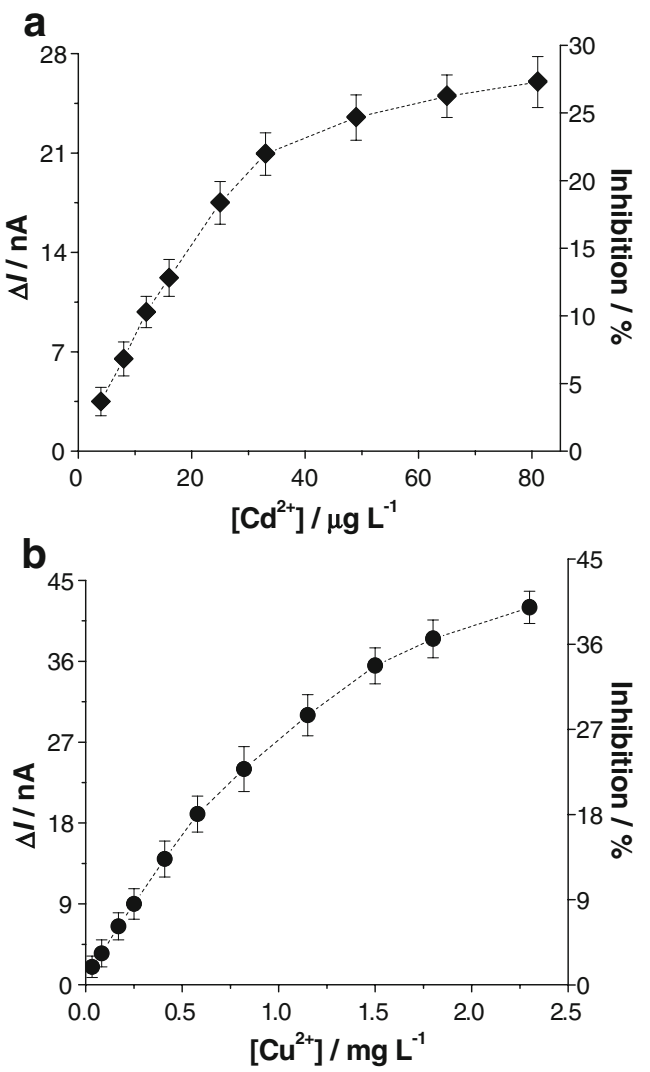

Fig. 2 Calibration curves for the determination of $\mathbf{a ~} \mathrm{Cd}^{2+}$ and $\mathbf{b ~ C \mathrm { Cu } ^ { 2 + }}$ in $0.1 \mathrm{M} \mathrm{NaPBS} \mathrm{pH} 7.0$ in the presence of $0.2 \mathrm{mM}$ glucose and the corresponding degree of inhibition

The inhibition constants were determined from Dixon plots [23], in which the inverse of enzyme activity is represented as a function of inhibitor concentration for at least two different enzyme-substrate concentrations. For a more accurate determination of this constant, the Dixon plots were constructed using three different glucose concentrations: $0.2,0.5$ and $1.0 \mathrm{mM}$ (Fig. 3). Following this method, the extrapolated straight lines intersect in a single point from which the inhibition constants were determined to be $K_{\mathrm{i}}\left(\mathrm{Cd}^{2+}\right)=100 \mu \mathrm{g} \mathrm{L}{ }^{-1}$ for cadmium and $K_{\mathrm{i}}\left(\mathrm{Cu}^{2+}\right)=3.9 \mathrm{mg} \mathrm{L}^{-1}$ for copper.

Using the same approach, the influence of lead and zinc cations was studied by performing experiments in the presence of fixed amounts of glucose in solution. Figure 4 shows the calibration curves for the determination of lead and zinc in the presence of $0.2 \mathrm{mM}$ glucose. Lead was measured between $83 \mu \mathrm{g} \mathrm{L}^{-1}$ and $1.5 \mathrm{mg} \mathrm{L}^{-1}$ (Fig. 4a) with a linear range up to $0.46 \mathrm{mg} \mathrm{L}^{-1}$ and a detection limit of $3 \mu \mathrm{g} \mathrm{L}^{-1}$. For zinc, the determination was performed between 0.41 and $14.5 \mathrm{mg} \mathrm{L}^{-1}$ (Fig. 4b) with a linear range up to $2.5 \mathrm{mg} \mathrm{L}^{-1}$ and a detection limit of $9 \mu \mathrm{g} \mathrm{L}^{-1}$ (Table 1). These low detection limits are comparable or even lower than those obtained in other studies using L-lactate dehydrogenase, alcohol oxidase or urease and glutamic dehydrogenase [10, 14, 24].

Using Eq. 1, the maximum inhibition observed for glucose oxidase in the presence of $0.2 \mathrm{mM}$ glucose was $16.1 \%$ for zinc and $22.5 \%$ for lead. Figure 5 shows the Dixon plots for lead and zinc using three different glucose concentrations of 0.2 , 0.5 and $1.0 \mathrm{mM}$. The inhibition constant for lead was determined to be $K_{\mathrm{i}}\left(\mathrm{Pb}^{2+}\right)=4.5 \mathrm{mg} \mathrm{L}$, and for zinc, it was not possible to determine the inhibition constant by this method because the lines are parallel.

In Fig. 6 is presented a comparison of the inhibition by the four different cations studied in this work. It is seen that there is a greater inhibition of glucose oxidase in the enzyme sensor by cadmium at low concentrations. Nevertheless, the degree of inhibition of cadmium appears to saturate (Fig. 3), and a higher percentage inhibition due to copper ions was observed. The inhibition by the other cations follows the order copper, then lead and, finally, zinc. With respect to cadmium, its high inhibition at such low concentrations is expected and was already reported for lactate dehydrogenase [12], but no reports with glucose oxidase have been found. In [14], the activity of alcohol oxidase was inhibited more by copper than by lead when using the same concentrations of both cations, the inhibition being $41 \%$ and $20 \%$, respectively, for 100 to $400 \mu \mathrm{g} \mathrm{L}^{-1}$ copper and lead ions. A high inhibition by copper was also obtained for glucose oxidase [19], copper being a stronger inhibitor than mercury, which is normally regarded as very toxic. Spectrophotometric studies suggested that there is not any considerable inhibition of glucose oxidase by lead ions for concentrations below $260 \mathrm{mg} \mathrm{L}^{-1}$ [15], the present study showing a much higher sensitivity to inhibition.

\section{Determination of the type of inhibition}

The Dixon plot is very useful for determining the inhibition parameters of metallic cations to the activity of glucose
Table 1 Analytical parameters for the determination of $\mathrm{Cd}^{2+}$; $\mathrm{Cu}^{2+} ; \mathrm{Pb}^{2+}$, and $\mathrm{Zn}^{2+}$ in the presence of $0.2 \mathrm{mM}$ glucose

$N D$ Not determined

\begin{tabular}{llllll}
\hline Ion & $\begin{array}{l}\text { Concentration range } \\
\text { tested/ } \mathrm{mg} \mathrm{L}^{-1}\end{array}$ & Linear range/ $\mathrm{mg} \mathrm{L}^{-1}$ & $\begin{array}{l}\text { Detection } \\
\text { limit/ } \mu \mathrm{g} \mathrm{L}^{-1}\end{array}$ & $K_{\mathrm{i}} / \mathrm{mg} \mathrm{L}^{-1}$ & $K_{\mathrm{i}}^{\prime} / \mathrm{mg} \mathrm{L}^{-1}$ \\
\hline $\mathrm{Cd}^{2+}$ & $0.004-0.081$ & $0.004-0.016$ & 1 & 0.1 & $\mathrm{ND}$ \\
$\mathrm{Cu}^{2+}$ & $0.033-2.3$ & $0.033-0.58$ & 6 & 3.9 & 1.1 \\
$\mathrm{~Pb}^{2+}$ & $0.083-1.5$ & $0.083-0.46$ & 3 & 4.5 & 2.8 \\
$\mathrm{Zn}^{2+}$ & $0.41-14.5$ & $0.41-2.5$ & 9 & $\mathrm{ND}$ & 5.3 \\
\hline
\end{tabular}


Fig. 3 a, c Dixon plot and b, d Cornish-Bowden plot for $\mathrm{Cd}^{2+}$ $(\mathbf{a}, \mathbf{b})$ and $\mathrm{Cu}^{2+}(\mathbf{c}, \mathbf{d})$ for three different glucose concentrations
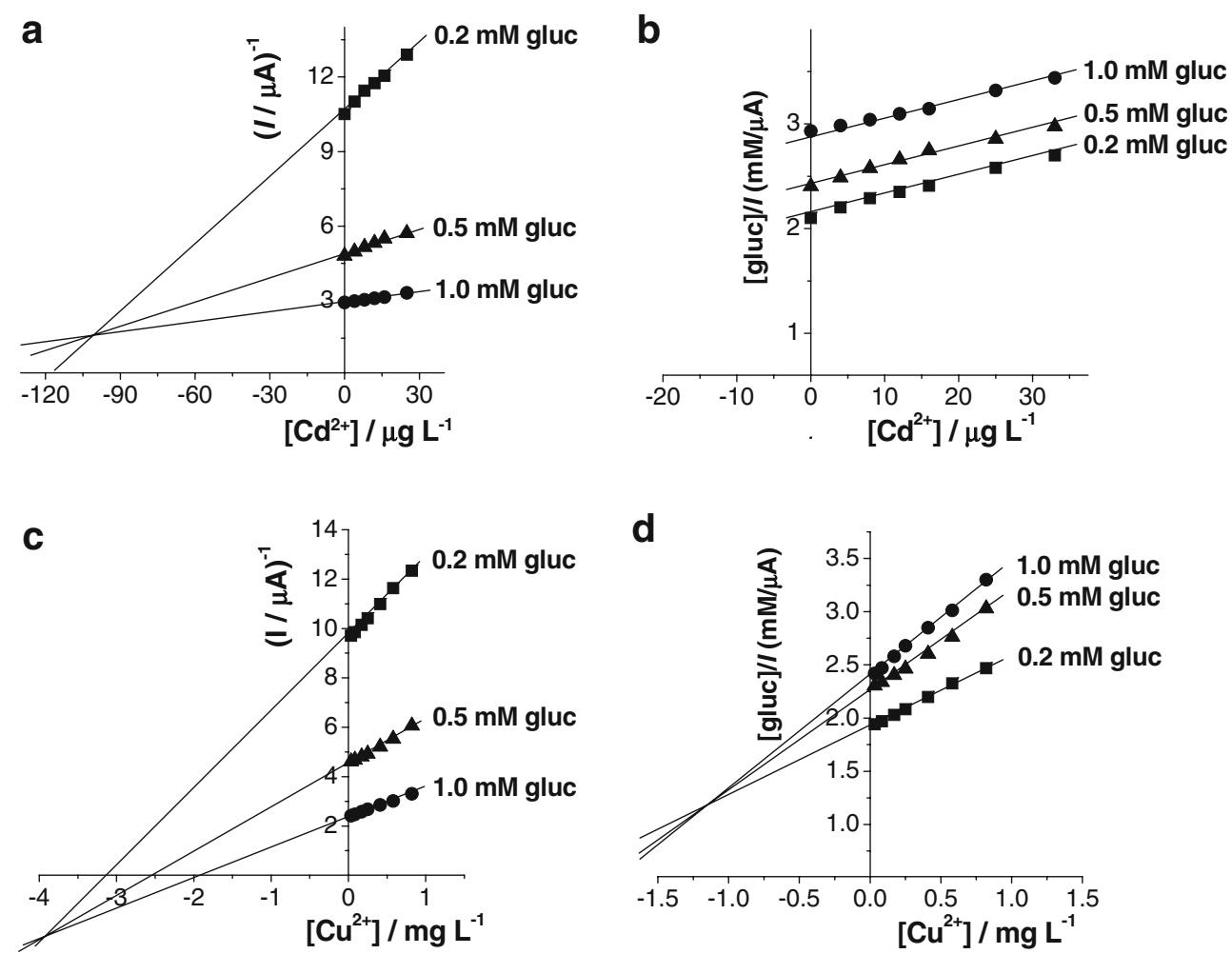

oxidase but is not sufficient to fully elucidate the type of inhibition, because the Dixon plot for mixed and competitive inhibition is similar. The complementary plot, the Cornish-Bowden plot [25] in which the ratio of substrate concentration and enzyme activity is plotted versus inhibitor concentration, allows the distinction between these two types of inhibition. This plot, by itself, is also not sufficient to fully determine the type of inhibition because it has the disadvantage of not always distinguishing between mixed and uncompetitive inhibition. However, by analysing the two plots together, all types of inhibition can be characterised.

Figures 3 and 5 show the Dixon plots and the CornishBowden plots for all four metal cations studied in this work using three different concentrations of glucose, 0.2, 0.5 and $1.0 \mathrm{mM}$. From the Dixon plot for cadmium, it can be deduced that the inhibition is mixed or competitive, but the Cornish-Bowden plot shows that the inhibition is, in fact, competitive because the three straight lines drawn through the experimental points are parallel. Further evidence that the mechanism of inhibition by the cadmium cation is competitive is the fact that inhibition is decreased by increasing the amount of substrate, from $27.4 \%$ in the presence of $0.2 \mathrm{mM}$ glucose to $18.8 \%$ in the presence of $1.0 \mathrm{mM}$ glucose.

For zinc, it is clear just from the Dixon plot that the inhibition is uncompetitive because the lines are parallel. Also, the opposite behaviour as for cadmium was observed: inhibition is increased by increasing the substrate concentration because the inhibitor has a high affinity for the enzyme-substrate complex. In this way, the inhibition
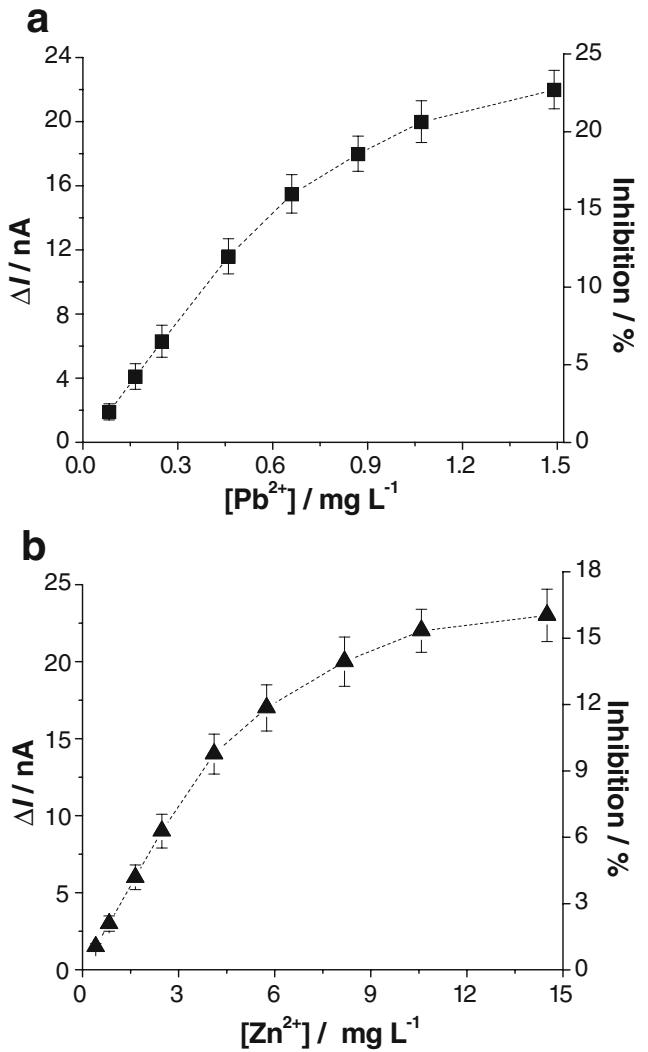

Fig. 4 Calibration curves for the determination of $\mathbf{a} \mathrm{Pb}^{2+}$ and $\mathbf{b ~} \mathrm{Zn}^{2+}$ in $0.1 \mathrm{M} \mathrm{NaPBS}$ pH 7.0 in the presence of $0.2 \mathrm{mM}$ glucose and the corresponding degree of inhibition 
Fig. 5 a, c Dixon plot and b, d Cornish-Bowden plot for $\mathrm{Pb}^{2+}$ $(\mathbf{a}, \mathbf{b})$ and $\mathrm{Zn}^{2+}(\mathbf{c}, \mathbf{d})$ for three different glucose concentrations a
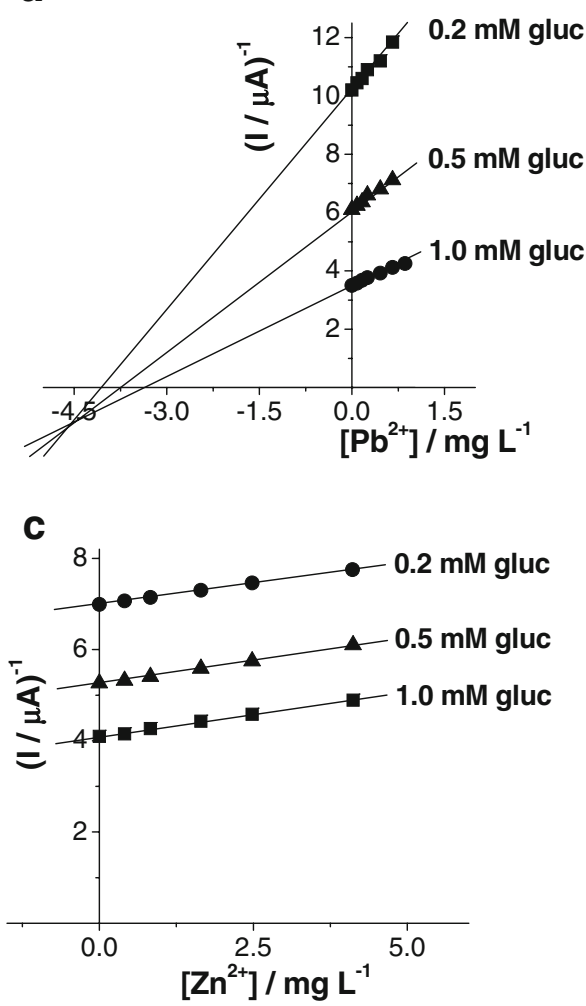

b

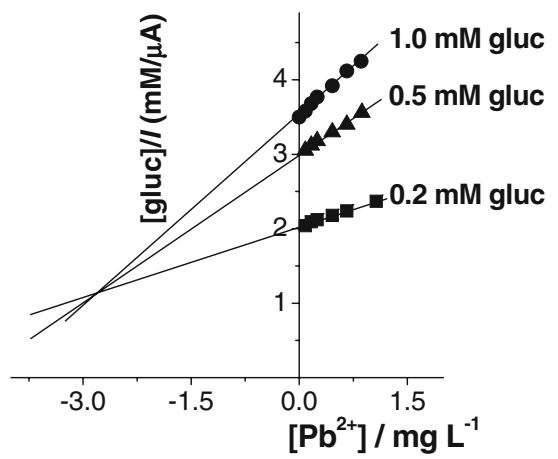

d

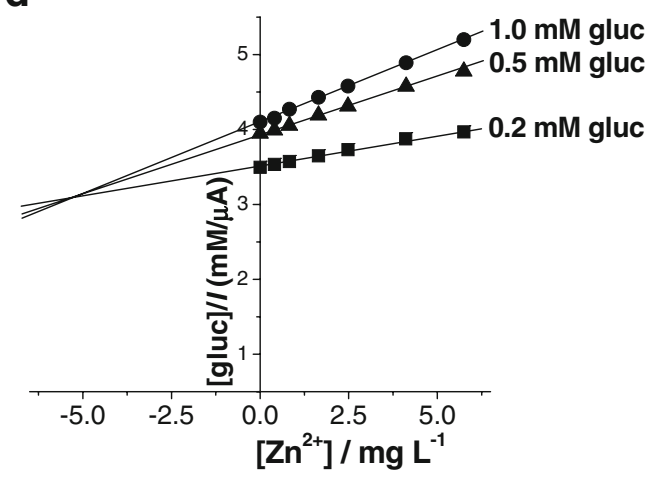

changed from $16.1 \%$ in the presence of $0.2 \mathrm{mM}$ glucose to $35.3 \%$ in the presence of $1.0 \mathrm{mM}$ glucose.

For the other two cations studied here, the plots showed mixed inhibition. Because $K_{\mathrm{i}}>K_{\mathrm{i}}^{\prime}$ (where $K_{\mathrm{i}}$, the inhibition constant, is the dissociation constant of the enzyme-inhibitor complex and $K_{\mathrm{i}}^{\prime}$ is the dissociation constant of the enzymesubstrate-inhibitor complex), in both cases, the intersection is above the inhibitor concentration axis in the CornishBowden plot and below the inhibitor axis in the Dixon plot [25].

Repeatability, reproducibility and stability of the biosensor

The repeatability of response of the PNR-GOx biosensor was investigated for fixed heavy metal ion concentrations. The relative standard deviation for three different assays with the same electrode was $6.9 \%, 5.6 \%, 5.4 \%$ and $7.4 \%$ for cadmium, copper, lead and zinc, respectively. For different electrodes, acceptable reproducibility was obtained for the determination of the same metal concentration with a variation coefficient of $5.4 \%(n=4)$ for cadmium, $10.8 \%$ $(n=3)$ for copper, $6.6 \%(n=3)$ for lead and $8.8 \%(n=3)$ for zinc.

The PNR-GOx biosensor was stored in phosphate buffer solution $\mathrm{pH} 7.0$ at $4{ }^{\circ} \mathrm{C}$ when not in use, after 3 weeks, the biosensor still maintaining $73 \%, 78 \%, 75 \%$ and $80 \%$ of its initial response for glucose for measuring cadmium, copper, lead and zinc. The relative extent of inhibition by the metal cations also decreased by $10-15 \%$.

The stability under continuous use, using the standard addition method for metal cations in the presence of fixed glucose concentration was also assessed. For the same metal concentration, it was observed that after six successive series of measurements, the biosensor lost $\sim 17 \%$ of the initial sensitivity for all four metal cations.

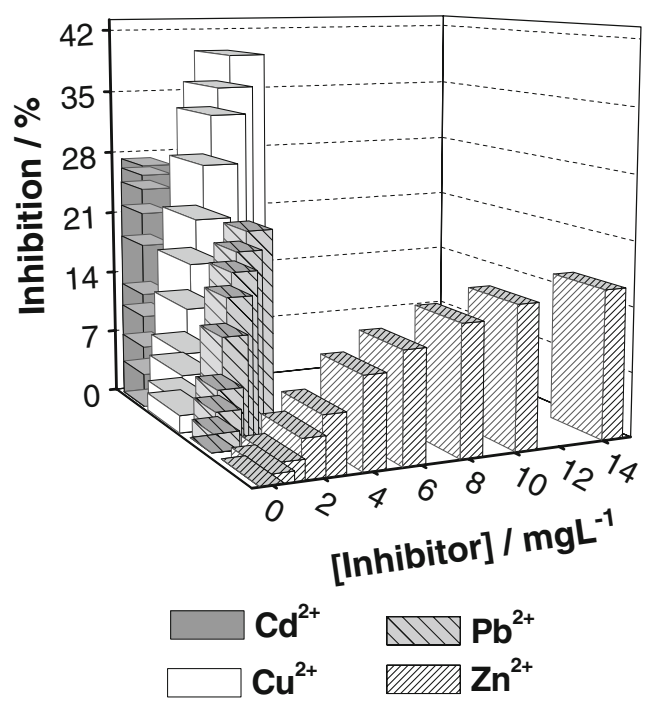

Fig. 6 The degree of inhibition of glucose oxidase as a function of metal ion concentration in the presence of $0.2 \mathrm{mM}$ glucose 

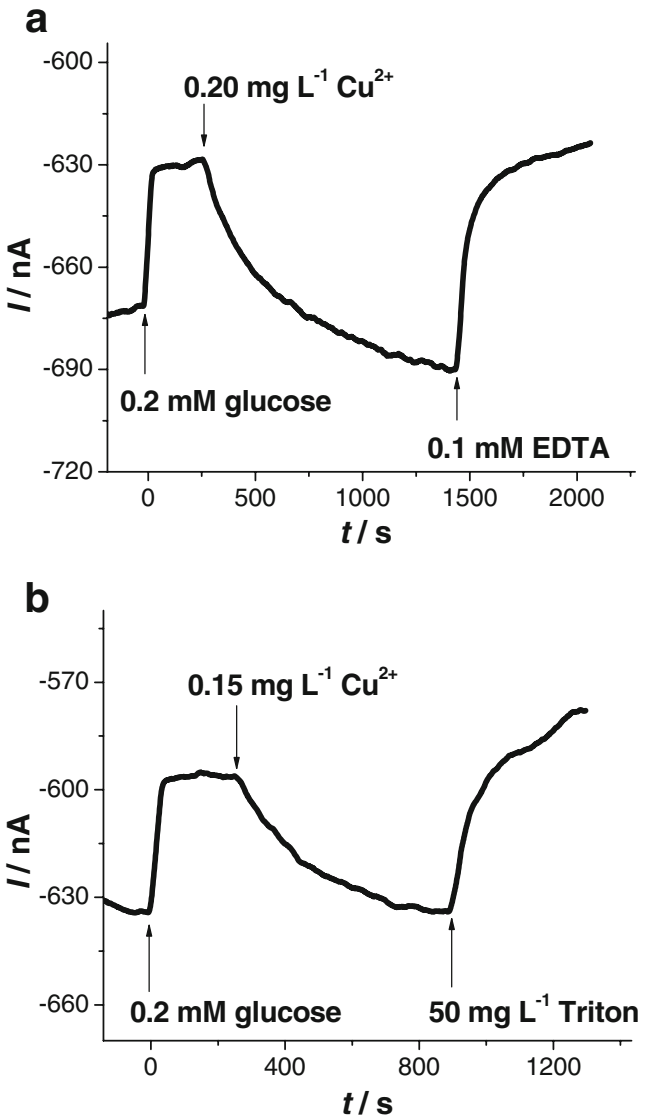

Fig. 7 The inhibition induced by $\mathrm{Cu}^{2+}$ in the presence of $0.2 \mathrm{mM}$ glucose and the response regeneration by a $0.1 \mathrm{M}$ EDTA and b $50 \mathrm{mg} \mathrm{L}^{-1}$ Triton

\section{Regeneration of glucose oxidase enzyme activity}

Understanding the mechanism of inhibition is necessary in order to know how to regenerate the activity of the inhibited enzyme. In general, in the case of metal cations, the interaction mechanism is not completely known, but the action revealed by different metals on the activity of oxidases and dehydrogenases is usually by binding of the metal salts to the thiol groups of the proteins [26-28]. The affinity of $\mathrm{Pb}^{2+}$ and $\mathrm{Cd}^{2+}$ for $\mathrm{SH}$ groups and of $\mathrm{Zn}^{2+}$ for carboxyl groups has already been reported [29]. In the same study, it was suggested that metal-induced enzyme inhibition could be due to the generation of radical oxygen species through a series of Fenton-type reactions, which can, in turn, denature the enzyme by causing conformational changes in its secondary and/or tertiary structure.

On the other hand, it was also reported that the inhibition by metal ions may not be due to blocking of the essential $\mathrm{SH}$ group but to a direct interaction between the FAD moiety of the enzyme and metal ions [30]. However, further investigation is needed in order to elucidate this point. For the regeneration of enzyme activity, several reagents or combination of reagents have been used, including the metal-chelating agent EDTA or thiols [8], cysteine [22] or a mixture of EDTA with dithiothreitol [12].

In the present study, the inhibition produced by the metallic cations is reversible, and it was observed that after each measurement, the activity of the inhibited enzyme is restored to about $90-96 \%$ after simply washing for 5 to $15 \mathrm{~min}$ in buffer solution. However, for sensor applications, a fast recovery time would be beneficial, so in order to see if it is possible to achieve a more rapid recuperation of enzyme activity, the addition of two different compounds was tested: EDTA and Triton X-100 non ionic surfactant.

As stated above, EDTA is a chelating agent which reacts with the metal ion leading to the formation of a stable complex, in this way removing the inhibitor and regenerating the enzyme activity. The nonionic surfactant Triton has the capacity of strongly adsorbing on surfaces and of forming micelles by aggregation at high concentration. In this way, it can form a protective layer on the surface of the electrode and impede the inhibitor reaching the immobilised enzyme, thus, helping to move the equilibrium towards dissociation of the inhibitor-enzyme complex.

In the case of copper, it was possible to recuperate the enzyme activity in about $100 \mathrm{~s}$ by adding $0.1 \mathrm{mM}$ EDTA, whereas addition of $50 \mathrm{mg} \mathrm{L} \mathrm{L}^{-1}$ of Triton to the buffer solution leads to recuperation of the response in about $150 \mathrm{~s}$ (see Fig. 7). For cadmium, lead and zinc, although full regeneration of enzyme activity occurred within approximately $100 \mathrm{~s}$ using EDTA or $150 \mathrm{~s}$ using Triton, it was difficult to optimise the experimental conditions.

It can be concluded that EDTA is more indicated for rapid biosensor regeneration in the case of inhibition by heavy metals at the glucose sensor studied, owing to its strong capacity to bind to the metal cations and keep them from reaching the enzyme. This method, by adding EDTA in solution, can be very helpful in the case of application in natural samples when rapid recuperation is needed without changing the buffer solution.

\section{Recovery test of heavy metals from natural samples}

The proposed method was applied to the determination of heavy metals in commercial milk samples. The samples were spiked with a known amount of metals, and the recovery of

Table 2 Recovery test of $\mathrm{Cd}^{2+} ; \mathrm{Cu}^{2+} ; \mathrm{Pb}^{2+}$, and $\mathrm{Zn}^{2+}$ from milk samples

\begin{tabular}{lccc}
\hline Ion & $\begin{array}{l}\text { Added concentration/ } \\
\mathrm{mg} \mathrm{L}^{-1}\end{array}$ & $\begin{array}{l}\text { Found concentration/ } \\
\mathrm{mg} \mathrm{L}^{-1}\end{array}$ & $\begin{array}{l}\text { Recovery } \\
(\%)\end{array}$ \\
\hline $\mathrm{Cd}^{2+}$ & 0.050 & $0.051 \pm 0.003$ & 102 \\
$\mathrm{Cu}^{2+}$ & 0.250 & $0.252 \pm 0.019$ & 101 \\
$\mathrm{~Pb}^{2+}$ & 0.50 & $0.53 \pm 0.031$ & 106 \\
$\mathrm{Zn}^{2+}$ & 2.5 & $2.43 \pm 0.12$ & 97 \\
\hline
\end{tabular}


the added metal cations was followed and compared to a standard curve in the developed system. Water was added to the milk samples in the ratio of 1:1 or 1:9 in order to have the same dilution when metal ions are added and were analysed with and without added metal cations. Recovery studies for $50 \mu \mathrm{g} \mathrm{L}^{-1}$ of cadmium, $250 \mu \mathrm{g} \mathrm{L}{ }^{-1}$ of copper, $500 \mu \mathrm{g} \mathrm{L}^{-1}$ of lead and $2.5 \mathrm{mg} \mathrm{L}^{-1}$ of zinc were performed in triplicate and the values were in the range of $97 \%$ to $105 \%$ (see Table 2).

The determination of cadmium, copper, lead and zinc was performed at levels that allow the application of this biosensor in wine samples, where the upper limits established by Office international de la Vigne et du Vin are $0.01,0.2,1.0$ and $5.0 \mathrm{mg} \mathrm{L}^{-1}$ for cadmium, lead, copper and zinc, respectively [31]. The biosensor may also be applied to the determination of copper and zinc in drinking water for which the European norm recommends values below $50 \mu \mathrm{g} \mathrm{L}^{-1}$ and $5 \mathrm{mg} \mathrm{L}^{-1}$, respectively [10].

\section{Conclusions}

The determination of the metal cations, cadmium, copper, lead and zinc has been performed by using a glucose biosensor with poly(neutral red) redox mediator. The metal ions were measured with low detection limits of 1, 3, 6 and $9 \mu \mathrm{g} \mathrm{L}^{-1}$ for cadmium, lead, copper and zinc, respectively. Inhibition constants were determined by using Dixon plots. All cations inhibited glucose oxidase, the enzyme being most sensitive to cadmium ions, although copper led to the highest degree of inhibition, followed by cadmium, lead and zinc. From Cornish-Bowden plots together with Dixon plots, the inhibition was determined to be reversible and competitive for cadmium, mixed for copper and lead and uncompetitive for zinc. Rapid regeneration of the enzyme response was achieved by using EDTA metal-chelating agent and nonionic surfactant Triton X-100, EDTA being more efficient. The heavy metal cations were determined at the microgram-perlitre concentration levels and recovery studies were successfully carried out with milk samples. These results open up new possibilities for detection of heavy metals as a measure of toxicity using a simple and low-cost procedure.

Acknowledgements Financial support from Fundação para Ciência e Tecnologia (FCT) Portugal, ICEMS (Research Unit 103) is gratefully acknowledged. M.E.G. thanks FCT for a PhD grant (SFRH/BD/14014/ 2003). Prof. H.-D. Liess is thanked for the gift of the electrical resistors.

\section{References}

1. Mushtakova VM, Fornina VA, Rogovin VV (2005) Toxic effect of heavy metals on human blood neutrophils. Biol Bull 32:276

2. Duruibe JO, Ogwuegbu MOC, Egwurugwu JN (2007) Heavy metal pollution and human biotoxic effects. Int J Phys Sci 2:112
3. Saracoglu S, Divrikli U, Soylak M, Elci L, Dogan M (2003) Determination of trace elements of some textiles by atomic absorption spectrometry. J Trace Microprobe Technol 21:389

4. Buzica D, Gerboles M, Borowiak A, Trincherini P, Passarella R, Pedroni V (2006) Comparison of voltammetry and inductively coupled plasma-mass spectrometry for the determination of heavy metals in PM10 airbone particulate matter. Atmos Environ 40:4703

5. Dugo G, La Pera L, Pellicanó TM, Di Bella G, D’Imperio M (2005) Determination of some inorganic anions and heavy metals in D.O.C. Golden and Amber Marsala wines: statistical study of the influence of ageing period, colour and sugar content. Food Chem 91:355

6. Brett CMA (1999) Electroanalytical techniques for the future: the challenges of miniaturization and of real-time measurements. Electroanalysis 11:1013

7. Brainina KZ, Stozhko NY, Belysheva GM, Inzhevatova OV, Kolyadina LI, Cremisini C, Galletti M (2004) Determination of heavy metals in wines by anodic stripping voltammetry with thick-film modified electrode. Anal Chim Acta 514:227

8. Evtugyn GA, Budnikov HC, Nikolskaya EB (1998) Sensitivity and selectivity of electrochemical enzyme sensors for inhibition determination. Talanta 46:465

9. Bontidean I, Berggren C, Johansson G, Csoregi E, Mattiasson B, Lloyd JA, Jakeman KJ, Brown NL (1998) Detection of heavy metal ions at femtomolar levels using protein-based biosensors. Anal Chem 70:4162

10. Fennouh S, Casimiri V, Geloso-Meyer A, Burstein C (1998) Kinetic study of heavy metal salt effects on the activity of Llactate dehydrogenase in solution or immobilized on an oxygen electrode. Biosens Bioelectron 13:903

11. Amine A, Cremisini C, Palleschi G (1995) Determination of mercury (II), methylmercury and ethylmercury in the $\mathrm{ng} / \mathrm{ml}$ range with an electrochemical enzyme glucose probe. Microchim Acta 121:183

12. Gayet JC, Haouz A, Geloso-Meyer A, Burstein C (1993) Detection of heavy metal salts with biosensors built with an oxygen electrode coupled to various immobilized oxidases and dehydrogenases. Biosens Bioelectron 8:177

13. vel Krawczyk TK, Moszczynska M, Trojanowicz M (2000) Inhibitive determination of mercury and other metal ions by potentiometric urea biosensor. Biosens Bioelectron 15:681

14. Pirvutoiu S, Dey E, Bhand S, Ciucu A, Magearu V, Danielsson B (2002) Application of the enzyme thermistor for determination of mercury and other heavy metals using free and immobilised alcohol oxidase. Roum Biotechnol Lett 7:975

15. Toren EC, Burger FJ (1968) Trace determination of metal ion inhibitors of the glucose-glucose oxidase system. Microchim Acta 56:538

16. Karyakin AA, Karyakina EE, Schmidt HL (1999) Electropolymerized azines: a new group of electroactive polymers. Electroanalysis $11: 149$

17. Ghica ME, Brett CMA (2006) Development of novel glucose and pyruvate biosensors at poly(neutral red) modified carbon film electrodes. Application to natural samples. Electroanalysis 18:748

18. Pauliukaite R, Ghica ME, Barsan MM, Brett CMA (2007) Characterisation of poly(neutral red) modified carbon film electrodes; application as a redox mediator for biosensors. J Solid State Electrochem 11:899

19. Malitesta C, Guascito MR (2005) Heavy metal determination by biosensors based on enzyme immobilised by electropolymerisation. Biosens Bioelectron 20:1643

20. Brett CMA, Angnes L, Liess HD (2001) Carbon film resistors as electrodes: voltammetric properties and application in electroanalysis. Electroanalysis 13:765

21. Filipe OMS, Brett CMA (2004) Characterization of carbon film electrodes for electroanalysis by electrochemical impedance. Electroanalysis 16:994 
22. Mohammadi H, Amine A, Cosnier S, Mousty C (2005) Mercury-enzyme inhibition assays with an amperometric sucrose biosensor based on a trienzymatic-clay matrix. Anal Chim Acta 543:143

23. Dixon M (1953) The determination of enzyme inhibitor constants. Biochem J 55:170

24. Rodriguez BB, Bolbot JA, TothillI E (2004) Development of urease and glutamic dehydrogenase amperometric assay for heavy metals screening in polluted samples. Biosens Bioelectron 19:1157

25. Cornish-Bowden A (1974) A simple graphical method for determining the inhibition constants of mixed, uncompetitive and non-competitive inhibitors. Biochem J 137:143

26. Amine A, Mohammadi H, Bourais I, Palleschi G (2006) Enzyme inhibition-based biosensors for food safety and environmental monitoring. Biosens Bioelectronm 21:1405
27. Gibbs PNB, Gore MG, Jordan PM (1985) Investigation of the effect of metal ions on the reactivity of thiol groups in human 5aminolaevulinate dehydratase. Biochem J 225:573

28. Tandogan B, Ulusu NN (2006) Effects of cadmium and zinc ions on purified lamb kidney cortex glucose-6-phosphate dehydrogenase activity. J Enz Inhib Med Chem 21:225

29. Aiken AM, Peyton BM, Apel WA, Petersen JN (2003) Heavy metal-induced inhibition of Aspergillus Niger nitrate reductase: applications for rapid contaminant detection in aqueous samples. Anal Chim Acta 480:131

30. Nakamura S, Ogura Y (1968) Mode of inhibition of glucose oxidase by metal ions. J Biochem 64:439

31. Aceto M, Abollino O, Bruzzoniti MC, Mentasti E, Sarzanini C, Malandrino M (2002) Determination of metals in wine with atomic spectroscopy (flame-AAS, GF-AAS, and ICP-AES); a review. Food Addit Contam 19:126 